\title{
Development and Optimization of a Real-Time Detection Assay for Xanthomonas fragariae in Strawberry Crown Tissue with Receiver Operating Characteristic Curve Analysis
}

\author{
W. W. Turechek, J. S. Hartung, and J. McCallister
}

First author: U.S. Department of Agriculture-Agricultural Research Service (USDA-ARS), U.S. Horticultural Research Laboratory, Fort Pierce, FL 34945; and second and third authors: USDA-ARS Fruit Laboratory, Beltsville, MD 20705.

Accepted for publication 6 November 2007.

\begin{abstract}
Turechek, W. W., Hartung, J. S., and McCallister, J. 2008. Development and optimization of a real-time detection assay for Xanthomonas fragariae in strawbverry crown tissue with receiver operating characteristic curve analysis. Phytopathology 98:359-368.

Angular leaf spot of strawberry is caused by the bacterium Xanthomonas fragariae. The disease is transmitted primarily through systemically infected nursery stock. This creates problems for nurseries wishing to export plants to Europe because of quarantine restrictions. Currently, field inspections for symptoms are used to certify plants free of $X$. fragariae, but visual inspection is not useful for detecting plants infected systemically. To detect systemic infections, polymerase chain reaction (PCR) is the desired tool because of its sensitivity, specificity, and ease of

primers for the detection of the bacterium $X$. fragariae in strawberry crown tissue. Real time detection proved to be both more sensitive and specific than standard PCR. Moreover, the detection of $X$. fragariae in crown tissue extract was possible with real-time PCR but not with standard PCR which is a significant improvement over standard PCR. The information on sensitivity and specificity of the primer sets was used to evaluate the performance of these primers with receiver operating characteristic (ROC) curve analysis under different tolerances. The results of this analysis can be used to provide guidance on threshold selection to manage disease below unacceptable levels. The results of this research may be useful to regulators and inspectors who must certify that plants meet European and Mediterranean Plant Protection Organization standards.
\end{abstract} use. In this study, we developed three sets of real-time PCR primers and probes and determined optimal reaction conditions for use of these
Additional keywords: black cap, Mann-Whitney $U$-statistic.
Angular leaf spot is caused by the bacterium Xanthomonas fragariae. The disease, first reported in Minnesota in 1962, occurs throughout the United States and in a number of strawberry growing regions in Europe, South America, Africa, Australia, and New Zealand $(14,17)$. The disease affects the foliage, often attacks the calyx (i.e., the sepals on fruit), and is known to move systemically within the plants vascular system where it may affect additional leaf tissue, crown tissue, and developing daughter plants (20). It is widely accepted that the introduction of the pathogen in production fields is through infected nursery stock. The EPPO (European and Mediterranean Plant Protection Organization) considers $X$. fragariae an A2 quarantine pathogen (i.e., a pathogen absent from the majority of the strawberry-growing countries in Europe, but has the potential to establish there) (27). Nurseries wishing to export plants to European countries must maintain certain phytosanitary standards. Specifically, planting material must be derived from mother plants certified free of $X$. fragariae and production sites should be documented free from angular leaf spot for the past five growing seasons.

Currently, nurseries rely mainly on field inspections to certify plants free of $X$. fragariae, but visual inspection is not useful for detecting plants infected systemically. To detect systemic infections, the polymerase chain reaction (PCR) (21) is the desired tool because of its sensitivity, specificity, and ease of use. Pooler et al.

Corresponding author: W. W. Turechek;

E-mail address: william.turechek@ars.usda.gov

doi:10.1094/PHYTO-98-3-0359

This article is in the public domain and not copyrightable. It may be freely reprinted with customary crediting of the source. The American Phytopathological Society, 2008.
(24) developed three primer sets for specific detection of $X$. fragariae using standard PCR: 241 (557 bp), 245 (305 bp), and 295 (634 bp). However, real-time or quantitative PCR (qPCR) is rapidly becoming the preferred platform because (i) it is quantitative, (ii) it can be completed more rapidly since no manipulations are required postamplification, (iii) identification of the amplification product with a hybridization probe has much better specificity than size analysis of products on gels, and (iv) there is much less chance of cross contamination of samples in the laboratory because the tube containing the amplification product is never opened. Thus, the development of qPCR primers could greatly facilitate the detection of $X$. fragariae infected plants and greatly improve the sensitivity of field and packinghouse surveys.

Diagnostic tests, including PCR, are not perfectly sensitive, particularly when pathogen prevalence is low, nor are they perfectly specific. In the case of the former, infected plants or batches of plants may escape detection when they should have been discarded. In the case of the latter, uninfected plants are mistakenly discarded. It is therefore important that the performance of any diagnostic tool be evaluated prior to its use so that users have a complete understanding of where errors occur to allow them to more accurately interpret results. Receiver operating characteristic (ROC) curve analysis is a statistical procedure used to evaluate the performance of diagnostic tools $(8,13,19,25)$. The ROC curve provides information showing how often a tool's diagnoses are correct, and provides a graphical method for evaluating and discriminating between different diagnostic tools or modifications of the same tool. ROC curve analysis not only facilitates the selection of the best diagnostic methods but, in more advanced applications, the ROC curve provides a means for risk management $(12,31)$. The methodology was introduced in the 
field of plant pathology about 10 years ago $(13,32)$, but its use has been limited to the evaluation of plant disease forecasters as predictors of epidemics at the scale of the management unit (e.g., field, orchard) $(5,28,29)$ rather than its traditional use in medicine as a means for selecting tools or tests for diagnosing the disease status of individuals.

The objectives of this research were to (i) develop qPCR primers for specific detection and quantification of $X$. fragariae, (ii) evaluate the performance of the primer pairs with ROC curve analysis, and (iii) provide information for the selection of optimal cutpoints.

\section{MATERIALS AND METHODS}

Bacterial strains and DNA extractions. $X$. fragariae strains Xf3, Xf6, and Xf128 were used in all experiments. Strains Xf3 and Xf6 originated from North Carolina and California, respectively, and were obtained from D. Ritchie (North Carolina State University, Raleigh, NC). Strain Xf128 was collected originally in Quebec and maintained by P. Roberts (University of Florida, Immokalee, FL). The bacteria were grown for 3 to 5 days at room temperature in sucrose-peptone broth (10) on an orbital table shaker. All samples were adjusted to an optical density $\left(\mathrm{OD}_{620}\right)$ of 1.0 and total genomic DNA was extracted from 1-ml aliquots and purified using Qiagen's DNeasy Tissue Kit (Qiagen Inc., Valencia, CA) according to manufacturer's instructions.

Primer development. TaqMan real-time PCR is a highly sensitive and specific PCR assay $(6,30)$. The increased specificity is attributable to the TaqMan probe which is complementary to the target DNA sequence amplified by PCR. The probe is labeled with a $5^{\prime}$ reporter dye and a $3^{\prime}$ quencher dye (in our case 6carboxy-fluorescein [FAM] and black hole quencher [BHQ-1], respectively). When the hybridization probe is intact, no fluorescence is detected. During PCR, the forward and reverse primers hybridize to the specific sequences of the target DNA and the TaqMan probe hybridizes to the target sequence internal to the primer sequences. Because both the primer and probe must hybridize to the target for amplification and cleavage to occur, nonspecific amplification is not detected. The increase in fluorescence is proportional to the amount of target that has been amplified during PCR, allowing quantification of the target DNA. The cycle number at which the fluorescent signal of the reporter exceeds background fluorescence is called the cycle-threshold $(\mathrm{Ct})$ value, and this value is compared to a standard curve to determine the initial quantity of DNA.

Three pairs of qPCR primers were developed from DNA sequences corresponding with the products amplified by the standard PCR oligonucleotide primers 241, 245, and 295 designed by Pooler et al. (24). To obtain the products for sequencing, the standard PCR protocol described by Pooler et al. (24) was modified as follows. Reactions were performed in $15 \mu \mathrm{l}$ volumes containing $1 \times$ Invitrogen PCR buffer, $200 \mu \mathrm{M}$ dNTP, $0.4 \mu \mathrm{M}$ of each primer, 0.3 units of Invitrogen Platinum Taq DNA polymer- ase, and $1 \mu \mathrm{l}$ of bacterial DNA as the template. DNA was amplified by denaturing DNA at $94^{\circ} \mathrm{C}$ for $15 \mathrm{~min}$, followed by an amplification profile of $94^{\circ} \mathrm{C}$ for $40 \mathrm{~s}, 52^{\circ} \mathrm{C}$ for $40 \mathrm{~s}$, and $72^{\circ} \mathrm{C}$ for $40 \mathrm{~s}$ for 35 cycles, and a final extension step of $72^{\circ} \mathrm{C}$ for $10 \mathrm{~min}$. PCR amplification was done in a Hybaid PCR Express thermal cycler (Thermo Electron Corp., Milford, MA). The PCR products were cloned in to plasmid pCR2.1 in Escherichia coli strain TOP10 with the TOPO TA Cloning Kit according to manufacturer's instructions (Invitrogen Corp., Carlsbad, CA). Several transformed colonies were selected for PCR analysis to verify successful transformation and a single transformed colony was selected for plasmid extraction and sequencing. Plasmid DNA was extracted using the Wizard Plus Minipreps DNA Purification System (Promega Corp., Madison, WI) according to manufacturer's instructions and the plasmid DNA was sequenced at the University of Maryland's Sequencing Facility. The sequence data was deposited in GenBank as accessions EU176814, EU176815, and EU176816. Specific primers and TaqMan probes were developed using Primer Express software (version 2.0, Applied Biosystems, Foster City, CA) (Table 1).

Reaction optimization. All reactions contained $2 \mu \mathrm{l}$ of DNA $(\approx 65 \mathrm{ng}$ ) extracted from $X$. fragariae strain Xf3. Reactions were run in a Cepheid SmartCycler (Cepheid Inc., Sunnyvale, CA) under the following conditions: DNA was denatured at $94^{\circ} \mathrm{C}$ for $20 \mathrm{~s}$ followed by an amplification profile of $94^{\circ} \mathrm{C}$ for $1 \mathrm{~s}$ and $58^{\circ} \mathrm{C}$ for $40 \mathrm{~s}$ for 40 cycles. For each of the three qPCR primer sets (q241, q245, and q295), optimal concentrations of forward and reverse primers, TaqMan probe, and $\mathrm{MgCl}_{2}$ were determined for a $25-\mu \mathrm{l} \mathrm{qPCR}$. Optimization was performed in a three step series of reactions (6). Fifteen combinations of concentrations of the reverse and forward primers were tested for every combination of $0.06,0.12,0.36$, and $0.60 \mu \mathrm{M}$. The $0.6 / 0.6 \mu \mathrm{M}$ combination was not tested because this created a final volume greater than $25 \mu$ li.e., master mix plus primers). The optimal primer concentrations for subsequent use were selected based on the reaction with the lowest $\mathrm{Ct}$ value. Optimal primer concentrations were tested with four concentrations of TaqMan probe: 0.07, 0.12, 0.17 , and $0.22 \mu \mathrm{M}$. The optimal combination of both primers and probes was then tested with six concentrations of $\mathrm{MgCl}_{2}: 2,3,4$, 5,6 , and $7 \mu \mathrm{M}$. Lastly, a gradient PCR was run to determine optimal annealing temperatures with the optimal reaction mixture. DNA extracted from strain Xf3 was selected for the test using a 100 -fold dilution of the standardized concentration. The gradient PCR was performed in a 96-well format using a Bio-Rad iQ5 real-time PCR detection system (Bio-Rad Laboratories, Hercules, CA). The annealing temperatures tested were 64.1, 63.6, 62.4, $60.5,58,56.2,54.9$, and $54.1^{\circ} \mathrm{C}$. These were centered on $58^{\circ} \mathrm{C}$ and set over a $10^{\circ} \mathrm{C}$ range; the specific temperatures around $58^{\circ} \mathrm{C}$ were selected by the iQ5 software based on the heating properties of the block. The reactions were performed in triplicate for each primer pair, and were run with an $X$. fragariae $\mathrm{Xf} 3$ positive control and a master-mix-only negative control.

TABLE 1. Optimum and/or recommended concentrations for a $25-\mu 1$ reaction of the forward and reverse primers, $T a q \mathrm{Man}$ probes, $\mathrm{MgCl}_{2}$, and recommended annealing temperatures for the primer sets q241, q245, and q295

\begin{tabular}{|c|c|c|c|c|c|}
\hline Primer/probe & Sequence $5^{\prime}-3^{\prime}$ & Master mix conc. & $\mathrm{MgCl}_{2}$ conc. & Annealing temperature & Size of product \\
\hline $\begin{array}{l}\mathrm{q} 241 \mathrm{f} \\
\mathrm{q} 241 \mathrm{r} \\
\text { Probe }\end{array}$ & $\begin{array}{l}\text { GCCCGACGCGAGTTGAATC } \\
\text { GGTCGAAAGTTACCGCCA } \\
\text { AGCATCTCCAAGCGAATGC }\end{array}$ & $\begin{array}{l}0.06 \mu \mathrm{M} \\
0.36 \mu \mathrm{M} \\
0.22 \mu \mathrm{M}\end{array}$ & $6 \mathrm{mM}$ & $55^{\circ} \mathrm{C}$ & $60 \mathrm{bp}$ \\
\hline $\begin{array}{l}\mathrm{q} 295 \mathrm{f} \\
\mathrm{q} 295 \mathrm{r} \\
\text { Probe }\end{array}$ & $\begin{array}{l}\text { CGTTCCTGGCCGATTAATAG } \\
\text { GTAATTTTCAGTTTGGTGATATTA } \\
\text { AAGCGACAAGAATGAAACCG }\end{array}$ & $\begin{array}{l}0.36 \mu \mathrm{M} \\
0.36 \mu \mathrm{M} \\
0.17 \mu \mathrm{M}\end{array}$ & $6 \mathrm{mM}$ & $55^{\circ} \mathrm{C}$ & $71 \mathrm{bp}$ \\
\hline
\end{tabular}

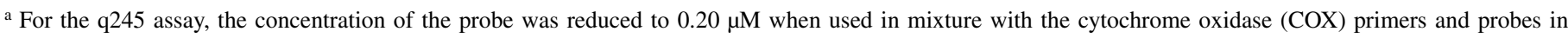
order to keep the volume of the reaction to $25 \mu \mathrm{l}$. 
Primer sensitivity and specificity. The sensitivities of the qPCR primer pairs were determined individually for (i) genomic DNA extracted from pure cultures of $X$. fragariae, (ii) whole cell bacteria, and (iii) DNA extracts from mixtures of strawberry crown tissue extract with whole cell bacteria. To prepare DNA extracts from pure culture, an aliquot from a 4-day-old sucrosepeptone liquid broth culture was adjusted to an optical density $\left(\mathrm{OD}_{620}\right)$ of 1.0. DNA was extracted from 1-ml aliquots of the standardized culture using both Qiagen's DNeasy Tissue Kit (appropriate for cultured cells) and Plant Mini Kit (used in practice for extractions from potentially infected plants) according to manufacturer's instructions. DNA was quantified with a NanoDrop ND-1000 spectrophotometer (NanoDrop Technologies, Wilmington, DE). Ten-fold serial dilutions were prepared from the DNA extracts as well as from the standardized whole cell bacteria culture. The whole cell dilution series was plated on sucrose peptone agar to obtain an estimate of the cell density in the standardized culture.

To prepare strawberry crown extract/bacteria cell mixtures, $10 \mu \mathrm{l}$ of each dilution of the whole cell bacteria culture was added to strawberry crown tissue extract. The extract was prepared by macerating $\approx 20 \mathrm{mg}$ of vascular tissue excised from the crown of a cold-stored strawberry plant in $404 \mu \mathrm{l}$ of Qiagen's DNA extraction buffer (i.e., AP1 buffer + RNAse A; the volume recommended for extraction) with a tissue macerator (Qbiogene, Carlsbad, CA). Thus, each tube contained approximately the same quantity of plant tissue but decreasing amounts of bacteria. DNA was extracted from each plant/bacteria mixture with Qiagen's Plant Mini Kit. Standard PCR and qPCR were performed on all dilution series as described above to determine the sensitivity and specificity of the qPCR primer pairs relative to the standard PCR primers. For the plant/bacteria mixture, primers that target the plant mitochondrial cytochrome oxidase (COX) gene and a corresponding probe were used as a plant-specific internal standard. This control ensures that the DNA extractions were successful and that reaction conditions are otherwise satisfactory (16). The forward and reverse primer sequences are: COX-F $=5^{\prime}$ GTA TGC CAC GTC GCA TTC CAG A $3^{\prime}$ and COX-R = 5' GCC AAA ACT GCT AAG GGC ATT C $3^{\prime}$, respectively. The probe sequence is: $\mathrm{COX}-\mathrm{P}=5^{\prime} / \mathrm{TET} / \mathrm{ATC}$ CAG ATG CTT ACG CTG G/BHQ/ with a 5' TET reporter dye and a black hole quencher. The primers and probe were included at a concentration of $0.12 \mu \mathrm{M}$. All reactions were performed in triplicate for each primer pair, and were run with an $X$. fragariae Xf3 positive control and a master-mix-only negative control.

Standard curves were generated for each set of serial dilutions by plotting the $\mathrm{Ct}$ value against the $\log$ of the concentration for the logarithmic phase of the reaction, and fitting this data by simple linear regression (6). The slope of the standard curve was used to determine the efficiency $(E)$ of the PCR: $E=10^{-1 / \text { slope }}-1$. Optimal PCR efficiency is achieved when a slope of -3.3 is achieved.

To test for primer specificity, DNA was extracted from pure cultures of 19 isolates of nine closely related Xanthomonads and 14 unknown bacteria isolated from the crown tissue of strawberry with Qiagen's DNeasy Tissue Kit using the method described above (Table 2). The 14 unknown bacteria were selected because they produced products in reactions with the standard PCR primers developed by Pooler et al. (24). The quantity of DNA extracted was determined with the NanoDrop ND-1000 spectrophotometer and reactions were performed as described above using $2 \mu \mathrm{l}$ of a 10-fold dilution of the extract as the target. Reactions were run in duplicate and each plate included an $X$. fragariae $\mathrm{Xf} 3$ positive control and a master-mix-only negative control.

ROC analysis. ROC analysis provides a statistical means for evaluating the performance of a diagnostic test. The qPCR data were partitioned into two groups based on whether they exceeded a predefined pathogen density or threshold, $D_{\text {thresh }}$, sometimes referred to as the tolerance. A case, denoted as $D+$, is defined as a test sample that is known to exceed the threshold value. Conversely, a control, denoted as $D$-, is a test sample that is known to not exceed the threshold value or tolerance. In our study, the cases and controls were manufactured artificially. Cases were prepared through serial dilutions, the controls were samples where no target DNA or bacteria was added or, where higher tolerances were permissible, the controls were samples where $D<D_{\text {thresh. }}$ In this study, cases and controls were partitioned according to one of three values of $D: 0$ (no tolerance), 10 , and 100 cells. When the tolerance is set to $D=0$, one is simply testing the capability of the diagnostic test to detect the target DNA in the population of cases, and the capability of nondetection in the control population. When the tolerance is set higher than 0 (e.g., $D=10$ or 100 cells), it is often done so because it is known or believed that the presence of the pathogen at this "tolerable" level introduces very little risk of initiating an epidemic when the tested plant material is planted in a commercial setting (7). In this scenario, the evaluation of the diagnostic test is to measure its ability to correctly classify samples as above or below the tolerance threshold.

In performing qPCR, samples are classified as positive $(T+)$ when the $\mathrm{Ct}$ value is less than an arbitrary cycle value called the cutpoint, $T_{c p}$. By convention, the cutpoint is often set to 35 . In other words, if the fluorescence generated from the reaction does not exceed the background fluorescence by the 35 th cycle, the

TABLE 2. List of bacterial species/pathovars tested, number of each species/pathovar tested, the host from which they were isolated, and the mean cycle threshold $(\mathrm{Ct})$ values for the three qPCR tests developed in the study

\begin{tabular}{|c|c|c|c|c|c|}
\hline \multirow[b]{2}{*}{ Strain } & \multirow[b]{2}{*}{ No. of isolates tested } & \multirow[b]{2}{*}{ Host } & \multicolumn{3}{|c|}{ Mean $\mathrm{Ct}^{\mathrm{a}}$} \\
\hline & & & 241 & 245 & 295 \\
\hline$X$. axonopodis pv. alfalfae & 1 & Alfalfa & $\mathrm{dnc}$ & dnc & $38.11^{(1)}$ \\
\hline$X$. axonopodis pv. begoniae & 1 & Begonia & $38.56^{(1)}$ & dnc & dnc \\
\hline X. axonopodis pv. dieffenbachiae & 1 & Philodendron & $38.04^{(2)}$ & $37.49^{(2)}$ & $36.80^{(1)}$ \\
\hline X. campestris pv. nigromaculans & 2 & Sorghum & dnc & $38.31^{(1)}$ & dnc \\
\hline$X$. hortorum pv. pelargonii & 1 & Geranium & $38.50^{(1)}$ & $37.62^{(1)}$ & $36.05^{(1)}$ \\
\hline$X$. axonopodis pv. vesicatoria & 1 & Tomato & $38.05^{(1)}$ & dnc & dnc \\
\hline$X$. campestris pv. zinniae & 2 & Zinnia & $38.16^{(2)}$ & $37.76^{(2)}$ & dnc \\
\hline X. smithii pv. aurantifolii & 4 & Citrus & dnc & $37.52^{(3)}$ & $37.80^{(3)}$ \\
\hline X. smithii pv. citri & 6 & Citrus & $38.45^{(2)}$ & $36.98^{(6)}$ & $36.76^{(5)}$ \\
\hline Unknowns & 14 & Strawberry & $36.85^{(7)}$ & $37.31^{(4)}$ & $36.03^{(10)}$ \\
\hline Average & & & 38.08 & 37.57 & 36.92 \\
\hline X. fragariae strain Xf3 (I) & 1 & Strawberry & 20.69 & 21.16 & 20.55 \\
\hline X. fragariae strain Xf3 (II) & 1 & Strawberry & 22.65 & 23.80 & 22.49 \\
\hline Negative control (master mix) & 4 & & dnc & dnc & dnc \\
\hline
\end{tabular}

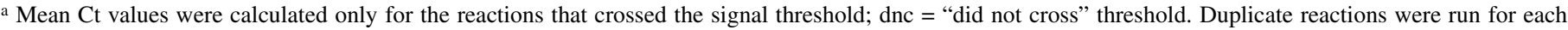
isolate tested and the number of reactions crossing the threshold out of the maximum of $2 \times$ "number of isolates tested" is shown in parentheses in superscript to the mean $\mathrm{Ct}$ value. 
sample is considered to be void of the target DNA and the sample is declared negative $(T-)$, irrespective of its true status as $D+$ or $D-$. However, $\mathrm{Ct}$ values can often exceed 35 when very small quantities of the target are present, resulting in false negative classifications. Conversely, if a tolerance other than 0 is selected, $\mathrm{Ct}$ values less than 35 are to be expected. Moreover, some primer pairs are sensitive to random amplification and/or may lack specificity resulting in false positive classifications. Some of these shortcomings may be resolved by selecting a cutpoint other than 35 and this can be accomplished through ROC curve analysis as described below.

The "sensitivity" of a diagnostic test is the conditional probability $P(T+\mid D+)$ and was calculated by dividing the number of true positive reactions $(T+)$ by the total number of cases. This is also referred to as the true positive proportion (TPP) and is the probability of detecting the pathogen in the population of individuals that are known to have exceeded the threshold. The "specificity" of a diagnostic is the conditional probability $P\left(T-\mid D_{-}\right)$and was calculated by dividing the number of true negatives by the total number of controls; this is referred to as the true negative proportion (TNP). It is the probability of nondetection in the population of samples that have not exceeded the threshold. The false positive proportion (FPP) is the conditional probability $P(T+$ $\mid D-)$ and is calculated as $1-$ specificity. Similarly, the false negative proportion (FNP) is the conditional probability $P(T-\mid D+)$ and is calculated as 1 - sensitivity (12).

ROC curves were created for each predictor as a plot of TPP (sensitivity) versus FPP ( 1 - specificity) by allowing the cutpoint $\left(T_{c p}\right)$ to vary over the continuous range of probable values (19). In a 40 cycle reaction, the $\mathrm{Ct}$ values can range from 0 to 40 ; however, we chose to model the data using $\mathrm{Ct}$ values from 28 thru 40 because this range of values was all that was needed to capture the full shape of the ROC curve. The area under the ROC (AUROC) curve and its standard error were calculated for each curve according to the methods of Hanley and McNeil (8) as implemented in Sigma Plot's (version 10) ROC curve analysis routine. In short, the calculations are based on the generalization that the AUROC curve is derived by dividing the Mann-Whitney $U$-statistic by the product of the two sample sizes. The MannWhitney $U$-statistic is defined as $\sum_{i=1}^{m} \sum_{j=1}^{n} U_{i j}$, where $U_{i j}=1,1 / 2$, or 0 if the $j$ th control is larger than, equal to, or smaller than the $i$ th case, respectively, $m$ and $n$ are the number of cases and controls, respectively, and $i$ and $j$ are indexing variables (22). The distribution of the Mann-Whitney $U$-statistic tends towards normality as the sample size increases, permitting the derivation of a $z$ statistic and a test of the hypothesis that the AUROC curve is no different than the area under the line of "no discrimination," i.e., 0.5. The $z$ statistic here is calculated with a continuity correction factor: $(|U-E(U)|-0.5) / \sqrt{ } \operatorname{Var}(U)$, where $\mathrm{E}(U)=m n / 2$ and $\operatorname{Var}(U)=$ $(m n / 12) \cdot\left[(m+n+1)-\sum_{i}\left(t_{i}^{3}-t_{i}\right) /(m+n)(m+n-1)\right]$ is the tiescorrected variance of $U\left(t_{i}\right.$ is the number of tied values in the $i$ th set of ties). For a two-sided test the $P$ value is calculated as 2. $\operatorname{Pr}(|Z|>z)$. A $95 \%$ confidence interval about the AUROC curve was calculated according to method 5 of Newcombe (23). This was done using the spreadsheet "generalisedmw1.xls" provided at Newcombe's website (published online by Cardiff University School of Medicine).

Pairwise comparisons of the AUROC curves were also done using Sigma Plot (version 10) ROC curve analysis routine. Briefly, the procedure implements a nonparametric approach for comparing the areas of two correlated ROC curves (4) using the method of structural components (26) to provide estimates of the elements of the variance-covariance matrix of the corresponding vector of $U$-statistics. Linear contrasts are then used to derive a chi-square statistic with degrees of freedom equal to the number of comparisons minus 1 .

The ROC curve is a graphical summary of the performance of a diagnostic test, expressed as a plot of its sensitivity and specificity for each cutpoint (28). Diagnostic decisions, however, require the user to select a single cutpoint along the ROC curve. If the ROC curve passes through the point $(0,1)$, it shows that the diagnostic test has at least one cutpoint possessing optimal sensitivity and specificity characteristics; however, this is rarely found. If sensitivity and specificity are considered equally important, such that the goal is to minimize the overall error rate, then the cutpoint closest to the point $(0,1)$ is considered the optimal cutpoint (19). This cutpoint, $T_{J}$, was identified for each of the ROC curves produced using Youden's index: $J=$ sensitivity + specificity -1 .

\section{RESULTS}

Primer development. The sequences of the products amplified by the oligonucleotide primers 241, 245, and 295 (24) are shown in Figure 1. The primers and probes developed from these sequences are shown also in Figure 1, as well as in Table 1. Each of the primer pairs shares one of the standard PCR primer pairs developed by Pooler et al. (24), with the exception of primer q245r which lacks the first nucleotide. No sequence matches were found in a basic local alignment search tool (BLAST) search of GenBank for any of the primer pairs developed.

Reaction optimization and efficiency. Optimum and/or recommended concentrations of the primers, TaqMan probes and $\mathrm{MgCl}_{2}$ were selected based on a combination of the $\mathrm{Ct}$ value, magnitude of fluorescence, and the shape of the reaction curve (Fig. 2; Table 1). Selection was also based on the practical gain in reaction sensitivity relative to the quantity of the master mix component in each test. For example, a reaction that consumed twice the volume of probe with only a marginal increase in sensitivity would be considered less desirable than the reaction that used half the volume of probe; particularly since the probe is the most expensive component of the master mix. The optimum annealing temperature was $55^{\circ} \mathrm{C}$ (rounded to the nearest degree Celsius) (Table 1). The optimum temperature was actually in the range of 54 to $55^{\circ} \mathrm{C}$ for $\mathrm{q} 245$ and 55 to $56^{\circ} \mathrm{C}$ for $\mathrm{q} 241$, but $55^{\circ} \mathrm{C}$ was selected so, in future applications, all three primer pairs could be used in a multiplexed reaction. The efficiency of the reactions were very close to 100 for extracted DNA of pure cultures and for the plant/bacteria mixture, but was slightly less efficient when applied to whole cells (Table 3).

Primer sensitivity and specificity; calculated cell numbers. Cell numbers were estimated from calculations based on the DNA mass in the standardized cell suspension (i.e., absorbance of 1.0 at $\mathrm{OD}_{620}$ ) obtained with the NanoDrop ND-1000 spectrophotometer, and dividing this value by the weight of a $5 \mathrm{Mbp}$ genome. This was our estimate of the weight of the $X$. fragariae genome based on reported weights of other plant pathogenic Xanthomonads (3, 15). Estimates of cell densities at higher dilutions were obtained by sequential division by 10 . The estimates of cell numbers were compared to those obtained by dilution plating, and those based on spectrophotometer absorbance data published by Hazel et al. (11). Estimates of cell numbers obtained by dilution plating were approximately an order of magnitude lower than those obtained with the NanoDrop (data not shown). This was not unexpected since dilution plating only provides information on living cells. Nanodrop estimates were within the same magnitude as those estimated by Hazel et al. (11).

Standard PCR. The sensitivity of standard PCR depended on whether PCR was performed with purified (extracted) DNA or whole cell bacteria (Fig. 3, bottom panels). Primer choice had little effect on the results. Purified DNA was detectable in approximately $20 \%$ of the reactions where the concentration of DNA was estimated to have been extracted from approximately 10 cells. The sensitivity was 100 -fold lower when PCR was run on whole cells, detecting cell concentrations in the order of magnitude of $10^{3}$ cells in approximately $35 \%$ of the cases. Standard PCR never detected bacteria in plant/bacteria extracts, pre- 
sumably due to PCR inhibitors in the plant extract; thus the sensitivity here was zero.

Real-time PCR. Similar to standard PCR, the sensitivity of qPCR reactions varied with the concentration of DNA or bacteria in the reaction, and whether the reaction was performed using purified DNA, whole cells, or purified DNA from plant/bacteria extract. Figure 3 (upper panels) shows the probability of detection or the sensitivity at $\mathrm{Ct}=35$. qPCR was more sensitive than standard PCR for all primer pairs. The sensitivity of the reaction was always greatest with purified DNA with each primer set having the ability to detect fewer than 10 cells greater than $50 \%$ of the time. Similar results were found using whole cells. However, the sensitivity in our tests was slightly higher at the highest dilution.
This may be the result of cell clumping. The sensitivity for purified DNA from plant and bacteria mixtures was surprisingly good, with the sensitivity rivaling that of purified DNA of the bacteria alone.

The specificity was measured two ways. The first measure was the ability of the qPCR assays to not generate false positive results when applied to the negative controls. The results can be visualized by reading the specificity measurements (Fig. 4A). The specificity was the best for q295. For this particular case, the values of $J$ in Table 4 indicates the highest $\mathrm{Ct}$ value where specificity $=100 \%$ for q241 and q245. The second measurement was obtained by examining for cross-reactivity with closely related bacteria (Table 2). The mean Ct values for the qPCR assays

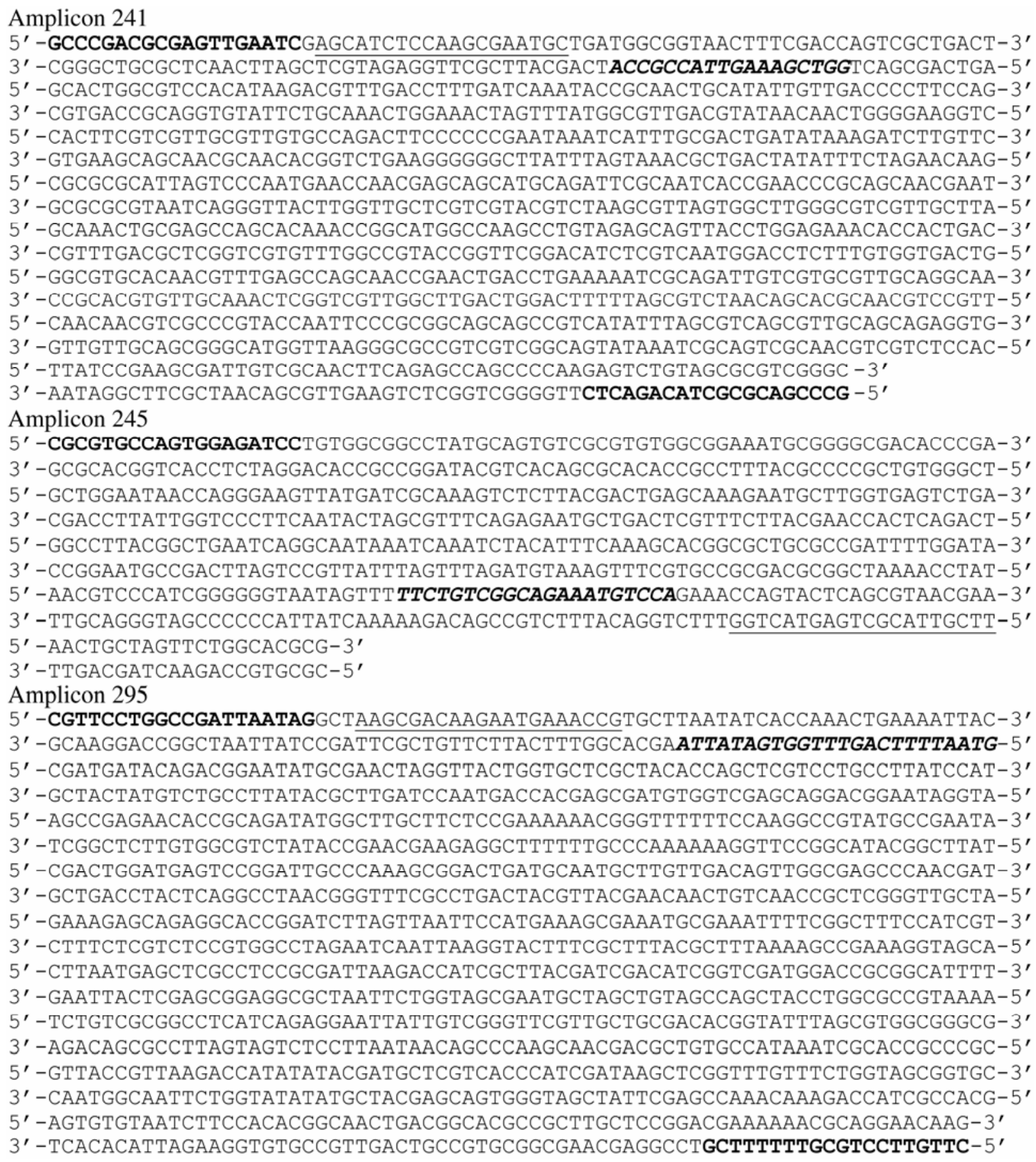

Fig. 1. DNA sequences of three amplification products useful for the identification of $X$. fragariae. Sequences are from strain Xf3. Primer sequences in boldface type at the ends of each amplicons were originally described by Pooler et al. (24). Sequences in italicized boldface type were paired with the nearest boldface primer for the real-time PCR assay. The underlined sequences between the boldface primers are the hybridization probes for the Taqman assay. Sequence data were deposited as GenBank accession nos. EU176814, EU176815, and EU176816. 
are shown in Table 2. The highest values were recorded for q295 followed by q245 then q241. In general, the majority of reactions had $\mathrm{Ct}$ values greater than $\mathrm{Ct}=36$ and were much higher than the $\mathrm{Ct}$ value for the $X$. fragariae positive control.

ROC analysis. The area under the ROC curve for all combinations of the three primer pairs, the three types of target DNA preparations, and the three tolerance levels were significantly greater than 0.5 according to the $z$ test (Fig. 4 and Table 4). Fiftyfive percent of the ROC curves had AUROCs greater than 0.94 and the lower confidence limit was greater than 0.75 for $70 \%$ of the ROC curves, indicating that the primer pairs had excellent diagnostic properties. The AUROCs were smaller for whole-cell preparations where cell clumping and/or cellular particulates may have interfered with the performance of the reaction. AUROCs were also smaller at lower tolerances (i.e., $D=0$ ) due to poorer sensitivity. When $D>0$, the ROC curve tended to flatten out due to losses in specificity. This is likely due to imperfect reaction efficiency as well errors associated with the inability to perfectly estimate cell density. In the latter, cases and controls would not be assigned correctly, particularly for samples where the true cell density was close to $D$.

For the pairwise comparisons, all primer pairs performed equivalently across all thresholds and preparations with the exception of q295 which performed poorer than q241 and q245 in whole cell preparations at the detection threshold of 0 cells (data not shown). Maximum values of $J$ were similar across the different sample preparations within the same tolerance group and are shown on Figure 4 and listed in Table 4 . $J$ did decrease with increasing tolerance, as would be expected given increasing levels of (permissible) DNA with increasing tolerance. For $D=0, J=\infty$ in cases where the $\mathrm{Ct}$ value of the negative control exceeded 40; this situation occurs with perfect specificity.

TABLE 3. The slope of the standard curve and the efficiency $(E)$ of real-time reactions performed on genomic DNA extracted from pure culture of Xanthomonas fragariae strain Xf3, whole cells of $X$. fragariae strain $\mathrm{Xf3}$, and purified DNA from mixtures of strawberry crown tissue extract spiked with whole cells of $X$. fragariae strain Xf3 for the primer sets q241, q245, and q295

\begin{tabular}{lccc}
\hline Test & Primer pair & Slope $^{\mathrm{a}}$ & Efficiency $^{\mathrm{b}}$ \\
\hline Extracted DNA & $\mathrm{q} 241$ & -3.20 & 105.2 \\
& $\mathrm{q} 245$ & -3.37 & 98.2 \\
Whole cells & $\mathrm{q} 295$ & -3.34 & 99.4 \\
& $\mathrm{q} 241$ & -3.42 & 96.0 \\
Plant and bacteria & $\mathrm{q} 245$ & -3.58 & 90.2 \\
& $\mathrm{q} 295$ & -3.55 & 91.2 \\
& $\mathrm{q} 241$ & -3.17 & 106.7 \\
& $\mathrm{q} 245$ & -3.31 & 100.5 \\
\hline
\end{tabular}

a The slope was estimated by regressing the cycle threshold value against the $\log$ of the concentration.

${ }^{\mathrm{b}}$ Calculated using $E=10^{-1 / \text { slope }}-1$. q241

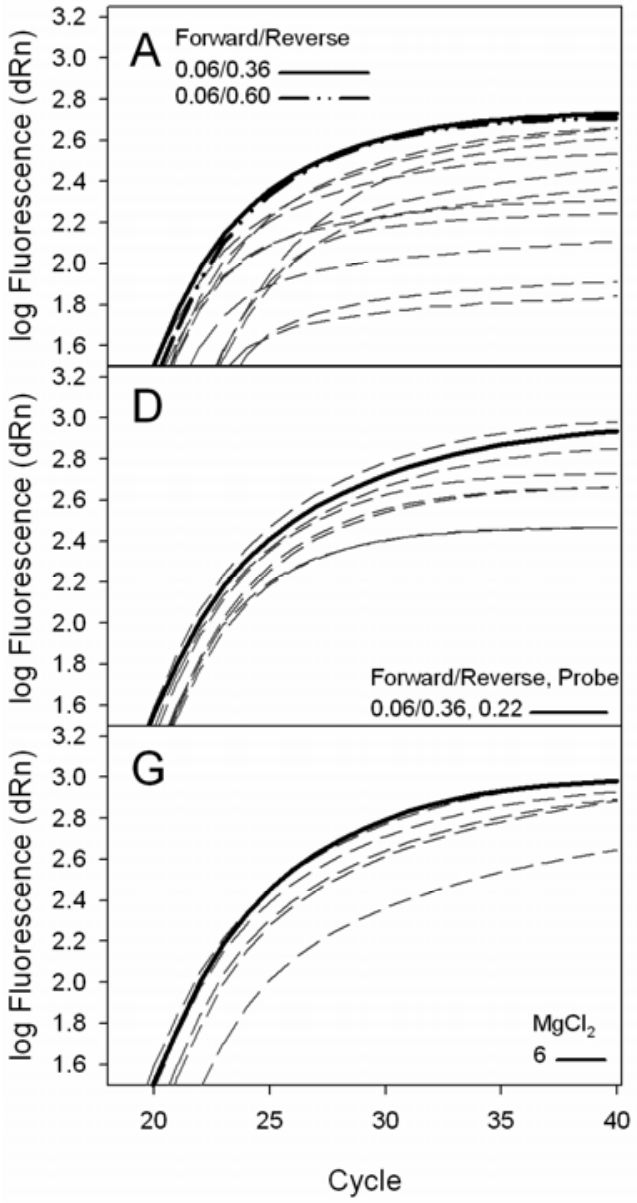

q245

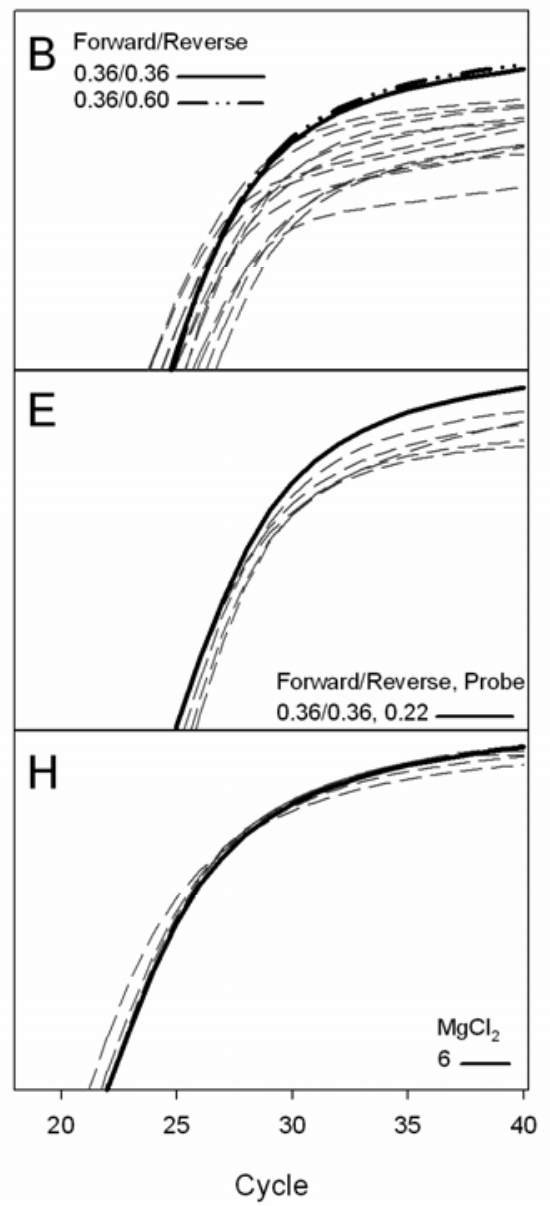

q295

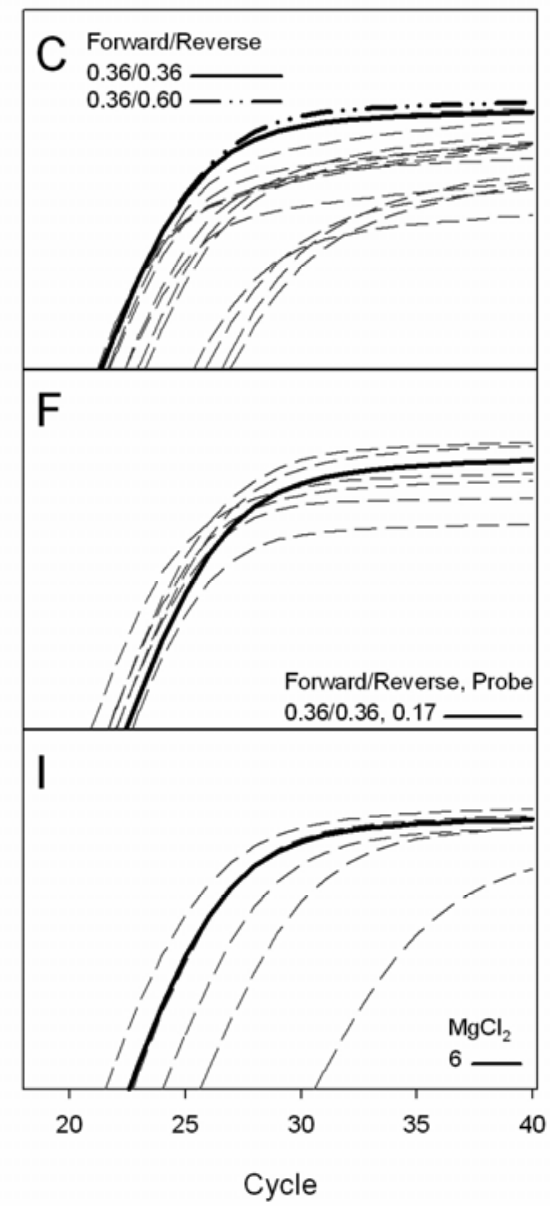

Fig. 2. Reaction curves for optimization experiments for A to C, 15 combinations of the reverse and forward primers tested using the Xf3 strain of Xanthomonas fragariae; the $0.6 / 0.6 \mu \mathrm{M}$ combination was not tested because this created a final volume greater than $25 \mu$ (i.e., master mix plus primers). The two optimum concentrations were selected based on a combination of the reaction with the lowest $\mathrm{Ct}$ value, shape of the reaction curve, and final level of fluorescence. The two reactions selected are identified and shown as thickened lines on its respective panel. D to F, Optimal primer concentrations were tested with 4 concentrations of TaqMan probe: $0.07,0.12,0.17$, and $0.22 \mu \mathrm{M}$ with the optimum identified as described above. G to I, The optimal combination of both primers and probes was then tested with 6 concentrations of $\mathrm{MgCl}_{2}: 2,3,4,5,6$, and $7 \mu \mathrm{M}$ with the optimum identified as described above. 


\section{DISCUSSION}

In this study, we developed three sets of real-time PCR primers and determined optimal reaction conditions for use of these primers for the detection of the bacterium $X$. fragariae. Real time detection proved to be both more sensitive and specific than standard PCR, as expected. Moreover, the detection of $X$. fragariae in crown tissue extract was possible with real-time PCR but not with standard PCR, which is a significant improvement over standard PCR. The information on sensitivity and specificity of the primer sets was used to evaluate these primers with ROC curve analysis. The analyses provided information on the performance of these primer pairs, and provided guidance on threshold selection at different tolerance levels.

The primer pairs developed in this research were based on the three sets of primers developed for use in standard PCR by Pooler et al. (24). All three real-time or qPCR primers shared one of the original standard PCR primers developed by Pooler et al. (24). The specificities of the standard PCR primers were tested originally with 36 isolates (representing 19 pathovars) of closely related Xanthomonads and 62 unidentified epiphytic bacteria isolated from field- and greenhouse-grown strawberry leaf tissue. Several of these bacteria were used to test the specificity of the real-time primers developed here with results consistent with those of the standard PCR primers. However, in the process of evaluating the qPCR primers, several colonies of bacteria were isolated from the crown tissue of 'Diamante' and 'Camarosa' strawberry that reacted with the standard PCR primers. The size of the product was larger or smaller than the predicted product, thus it was still possible to discern $X$. fragariae from other bacteria. In any event, these bacteria were not detected with any of the qPCR primers, possibly due to the added level of specificity afforded by the TaqMan probe.

We were never able to achieve amplification of the target DNA when running standard PCR primers on genomic DNA extracted from the mixture of bacteria and strawberry crown tissue extract. We assumed that PCR inhibitors present in the crown tissue extract were not eliminated or satisfactorily reduced to allow the standard PCR to occur. Thus, we tried a number of common DNA extraction kits/methods including RedExtract-N-Amp Tissue PCR kit (Sigma-Aldrich), Qiagen's DNeasy Tissue kit (appropriate for cultured cells) and Plant Mini kit, and cetyltrimethylammonium bromide (CTAB) DNA isolation and were still not able to achieve amplification. Target DNA amplification was possible, however, with all of the qPCR primers when extraction was performed with Qiagen's kits as well as the CTAB method (we did not try RedExtract-N-Amp with qPCR). The shorter amplification products (60 to $71 \mathrm{bp}$ in qPCR compared with 305 to $634 \mathrm{bp}$ standard PCR) likely explains why the real-time assay was not affected by plant inhibitors of PCR. In earlier work, target bacteria were removed from strawberry extracts by immunocapture prior to assay by standard PCR in order to overcome inhibition of PCR by strawberry extracts (9).

In addition to their increased specificity, ease of use and rapid and quantitative results, all three qPCR assays were more sensitive than their corresponding standard format PCR assays. However, the useful level of sensitivity provided by the assay is controlled by the user in consideration of the purpose of the assay. The user chooses the threshold for differentiating between true signal and background fluorescence, and also chooses the maximum reaction cycle number (the cycle threshold or $\mathrm{Ct}$ value) used to differentiate between a positive and negative test result. In the case of the former, it is typical for this threshold to be set by the manufacturer or for it to be selected according to machine-specific software, although there is often the option to allow the user to select this threshold. We preferred to use the manufacturers pre-set recommendation for the SmartCycler and allowed the software to select the threshold for the iQ5. In the case of the latter threshold, it is somewhat standard to select $\mathrm{Ct}=35$ as the cut-off value. This value is reasonable, but it is conservative if the ultimate goal is detection (i.e., $D=0$ ). If the target DNA is expected to be present at particularly low levels, then $\mathrm{Ct}$ values greater than 35 may be chosen. The selection is usually done at the discretion of diagnostician and is often a function of the tolerance for the pathogen and, less often, the performance of the assay. But it should be clear that when doing so, that for any single test possessing imperfect sensitivity and specificity, selecting a threshold to favor either character compromises the other one because there is a fundamental, mathematical trade off between sensitivity and specificity in any diagnostic assay such as this one.

The ROC curves in Figure 4 provide the necessary information on the performance of the diagnostic so that thresholds can be selected appropriately. The larger symbols in each graph represent the Ct values identified by Youden's Index and are the thresholds that provide an equal balance between sensitivity and specificity. The ROC curves under $D=0$ in Figure 4 represent the performance of the qPCR assays when the tolerance for the pathogen is 0 .
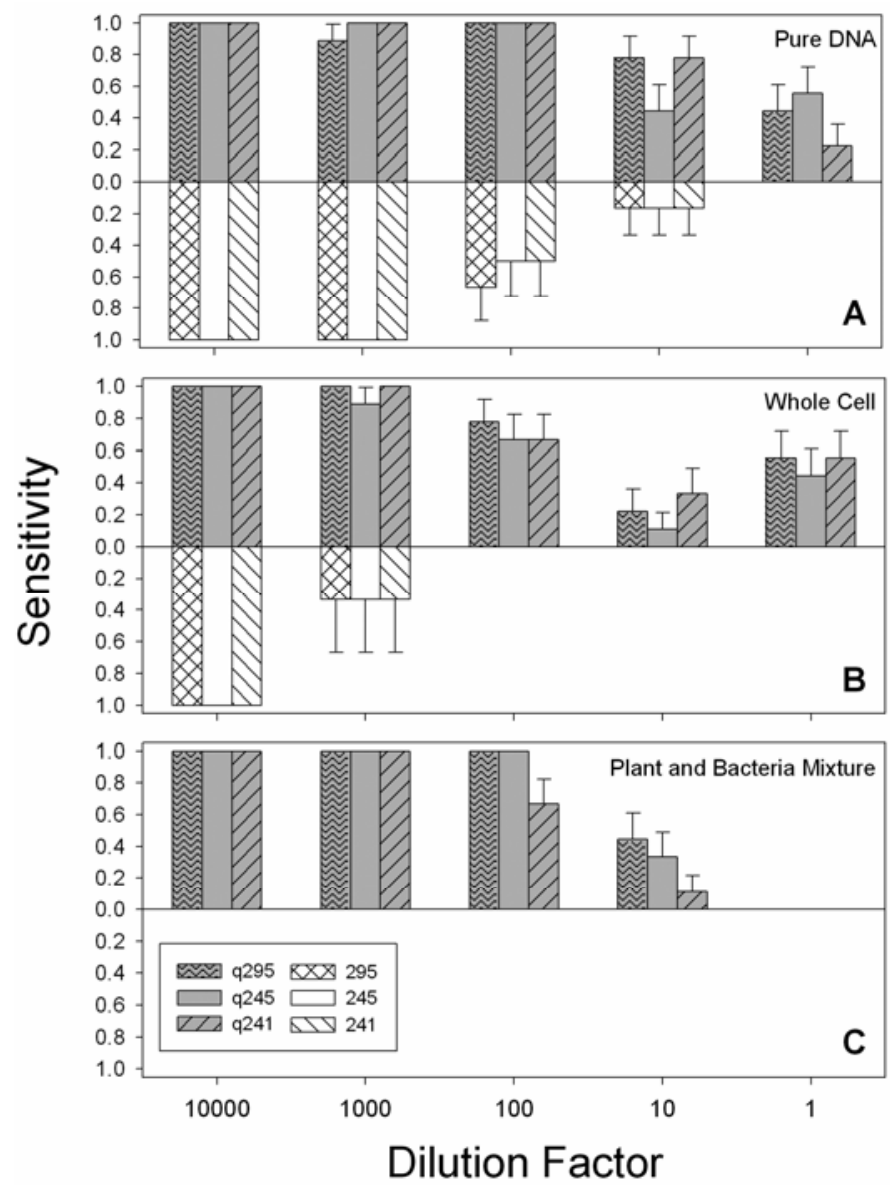

Fig. 3. The sensitivity of qPCR (upper panel) and standard PCR (lower panel) for reactions performed on serial dilutions to detect A, genomic DNA extracted from pure cultures of Xanthomonas fragariae, $\mathbf{B}$, whole cells of $X$. fragariae, and $\mathbf{C}$, genomic DNA extracted from mixtures of crown tissue and bacteria. The sensitivity is the number of samples testing positive for the target DNA as a proportion of the total number of samples that actually contained the target. For qPCR, sensitivity calculations were done by grouping results from reactions of all three strains of bacteria (i.e., Xf3, Xf6, and Xf128), thus each bar represents the mean sensitivity of 9 observations. For standard PCR, sensitivity calculations were done by grouping results from reactions of all three bacteria. Thus, for measurements of sensitivity of DNA extractions from pure culture, each bar represents the mean of 18 observations ( 3 repetitions from each of 3 bacteria from each of 2 extraction methods), and each bar for the whole cell tests was calculated from 9 observations (3 repetitions from each of 3 bacteria). 


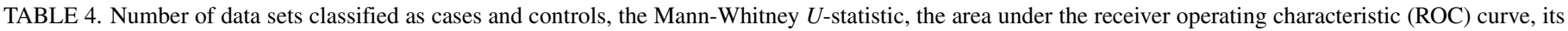

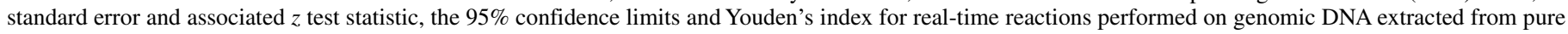

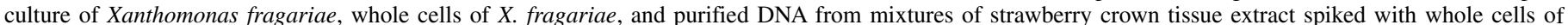
$X$. fragariae strain Xf3 bacteria with the primer sets q241, q245, and q295

\begin{tabular}{|c|c|c|c|c|c|c|c|c|c|c|}
\hline Q-PCR test & $D_{\text {thresh }}{ }^{\mathrm{a}}$ & Case $^{b}$ & Control $^{b}$ & $U^{\mathrm{c}}$ & AUROC $^{d}$ & $\mathrm{se}_{\mathrm{AUC}}{ }^{\mathrm{d}}$ & $z^{\mathrm{e}}$ & $\mathrm{CI}_{\text {Lower }}^{\mathrm{f}}$ & $\mathrm{CI}_{\text {Upper }}^{\mathrm{f}}$ & $J^{\mathrm{g}}$ \\
\hline \multirow[t]{3}{*}{ Purified DNA q241 } & 0 & 45 & 9 & 381 & 0.9407 & 0.031 & 4.15 & 0.7713 & 0.9852 & 35.64 \\
\hline & 10 & 36 & 18 & 628 & 0.9691 & 0.021 & 5.58 & 0.8625 & 0.9931 & 34.27 \\
\hline & 100 & 27 & 27 & 716 & 0.9822 & 0.013 & 6.08 & 0.8931 & 0.9970 & 31.89 \\
\hline \multirow[t]{3}{*}{ Purified DNA q245 } & 0 & 45 & 9 & 357 & 0.8815 & 0.048 & 3.59 & 0.6920 & 0.9572 & 34.80 \\
\hline & 10 & 36 & 18 & 560 & 0.8642 & 0.060 & 4.33 & 0.7191 & 0.9370 & 34.11 \\
\hline & 100 & 27 & 27 & 692 & 0.9492 & 0.035 & 5.66 & 0.8419 & 0.9839 & 33.32 \\
\hline \multirow[t]{3}{*}{ Purified DNA q295 } & 0 & 45 & 9 & 400.5 & 0.9889 & 0.011 & 4.60 & 0.8470 & 0.9992 & $\infty$ \\
\hline & 10 & 36 & 18 & 613.5 & 0.9468 & 0.029 & 5.31 & 0.8286 & 0.9837 & 34.26 \\
\hline & 100 & 27 & 27 & 700.5 & 0.9609 & 0.032 & 5.81 & 0.8592 & 0.9892 & 32.88 \\
\hline \multirow[t]{3}{*}{ Whole cells q241 } & 0 & 45 & 9 & 400.5 & 0.9889 & 0.011 & 4.60 & 0.8470 & 0.9992 & $\infty$ \\
\hline & 10 & 36 & 18 & 531.5 & 0.8202 & 0.068 & 3.81 & 0.6667 & 0.9080 & 37.14 \\
\hline & 100 & 27 & 27 & 641 & 0.8793 & 0.052 & 4.78 & 0.7480 & 0.9440 & 34.13 \\
\hline \multirow[t]{3}{*}{ Whole cells q245 } & 0 & 45 & 9 & 378 & 0.9333 & 0.026 & 4.07 & 0.7607 & 0.9822 & $\infty$ \\
\hline & 10 & 36 & 18 & 534 & 0.8241 & 0.058 & 3.85 & 0.6711 & 0.9106 & 37.41 \\
\hline & 100 & 27 & 27 & 671 & 0.9204 & 0.035 & 5.31 & 0.8015 & 0.9687 & 34.80 \\
\hline \multirow[t]{3}{*}{ Whole cells q295 } & 0 & 45 & 9 & 351 & 0.8667 & 0.049 & 3.45 & 0.6737 & 0.9492 & 35.31 \\
\hline & 10 & 36 & 18 & 545.5 & 0.8418 & 0.052 & 4.06 & 0.6920 & 0.9225 & 34.38 \\
\hline & 100 & 27 & 27 & 689 & 0.9451 & 0.028 & 5.61 & 0.8359 & 0.9818 & 34.03 \\
\hline \multirow[t]{3}{*}{ Plant/bacteria q241 } & 0 & 45 & 9 & 355.5 & 0.8778 & 0.032 & 3.55 & 0.6874 & 0.9553 & $\infty$ \\
\hline & 10 & 36 & 18 & 619.5 & 0.9560 & 0.025 & 5.42 & 0.8423 & 0.9878 & 37.44 \\
\hline & 100 & 27 & 27 & 715 & 0.9808 & 0.013 & 6.07 & 0.8908 & 0.9966 & 34.64 \\
\hline \multirow[t]{3}{*}{ Plant/bacteria q245 } & 0 & 45 & 9 & 364.5 & 0.9000 & 0.030 & 3.76 & 0.7157 & 0.9668 & $\infty$ \\
\hline & 10 & 36 & 18 & 637.5 & 0.9838 & 0.015 & 5.75 & 0.8865 & 0.9977 & 37.17 \\
\hline & 100 & 27 & 27 & 720 & 0.9877 & 0.010 & 6.15 & 0.9025 & 0.9984 & 34.88 \\
\hline \multirow[t]{3}{*}{ Plant/bacteria q295 } & 0 & 45 & 9 & 373.5 & 0.9222 & 0.027 & 3.97 & 0.7453 & 0.9773 & $\infty$ \\
\hline & 10 & 36 & 18 & 631.5 & 0.9745 & 0.018 & 5.64 & 0.8711 & 0.9950 & 35.56 \\
\hline & 100 & 27 & 27 & 719 & 0.9863 & 0.010 & 6.13 & 0.9001 & 0.9981 & 34.65 \\
\hline
\end{tabular}

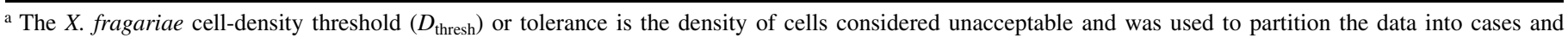
controls (the threshold is chosen arbitrarily).

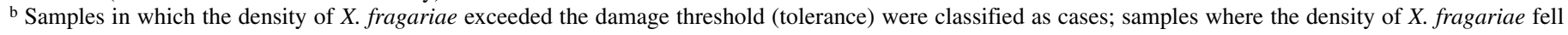
below the tolerance were classified as controls.

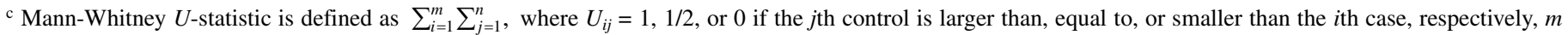
and $n$ are the number of cases and controls, respectively, and $i$ and $j$ are index variables.

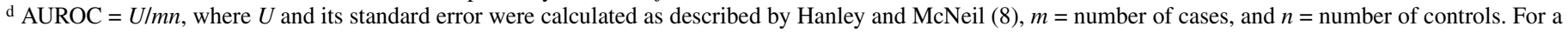
perfect diagnostic test, the AUROC is one; tests that have no power to discriminate the AUROC $=0.5$.

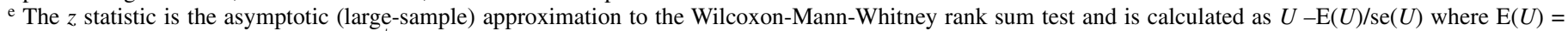
$m n / 2$ and $\operatorname{se}(U)$ is the ties-corrected $\sqrt{ } \operatorname{Var}(U)$ as described in the text. The $P$ value was calculated as $2 \cdot \operatorname{Pr}(|Z|>z)$; values greater than 1.96 indicate significance at $\alpha=0.05$.

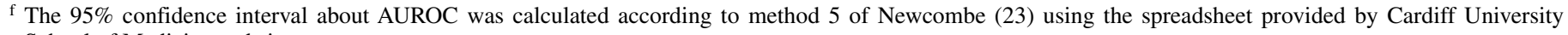
School of Medicine website.

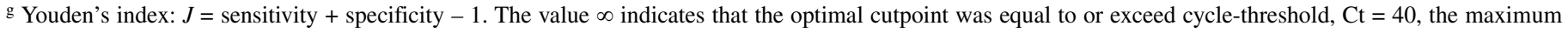
number of cycles performed.

In nearly all cases, the optimal threshold ( $\mathrm{Ct}$ value) identified by $J$ is higher than 35. For tests of purified bacterial DNA, for example, a near perfect test is possible with primer set q295 if the $\mathrm{Ct}$ value is raised to 40. Allowing for some tolerance of the pathogen, a gain in sensitivity is achieved for q241 and q245, but at a cost of specificity. For values of $D$ greater than zero, optimal thresholds $(\mathrm{Ct})$ are less than 35 . This is because real-time PCR is quantitative and the $\mathrm{Ct}$ value is related directly to the quantity of target DNA. In such cases, samples that actually contain target bacteria equal to or lower than $D$ will be correctly declared negative. This is a bit of an unnatural call for most diagnosticians who typically declare any sample with the pathogen as positive.

When testing for the pathogen in strawberry crown extracts, it should be evident that a substantial gain in sensitivity could be accomplished if some tolerance for the pathogen is permitted, but at a cost of specificity. The user must weigh the probability of initiating an epidemic from 10 cells (or 100 cells) against the gain in sensitivity of the assay to detect the low numbers of target bacteria. Unfortunately, the information needed to make this decision is currently lacking, but would be a worthwhile project to pursue. Further, qPCR assays detect DNA from both living and dead cells. These questions are important when establishing thresholds for an assay intended for routine use. It is of course tempting to simply set $D=0$, but this is a bit naïve since it ignores the fact that the test does not possess perfect sensitivity.

The AUROC and the accompanying test of significance are based on the Mann-Whitney $U$-statistic. These calculations can be performed in several statistical packages or manually. In the process of doing these calculations and comparing calculations across software packages, it quickly became evident that the calculated $z$ statistic and/or $P$ values can be different when calculated using the same input data with different software packages. This would lead ultimately to different conclusions. There are at least three reasons why this occurs and these are discussed in greater detail by Bergmann et al. (1). (i) In calculating the distribution of the Mann-Whitney $U$-statistic either the large-sample (asymptotic) approximation (normal or $\chi^{2}$ distribution) or the exact permutation distribution may be used, (ii) the large-sample approximation may be calculated with or without a correction for continuity, and (iii) the ties-corrected variance may or may not be used with the large-sample approximation. Unfortunately, software documentation is not always complete and the user is left wondering how the statistics were calculated (1). Therefore the reader should confirm the details of the calculations used by software rather than relying blindly on it. The calculations described in this manuscript match the output for Sigma Plot's ROC module. 


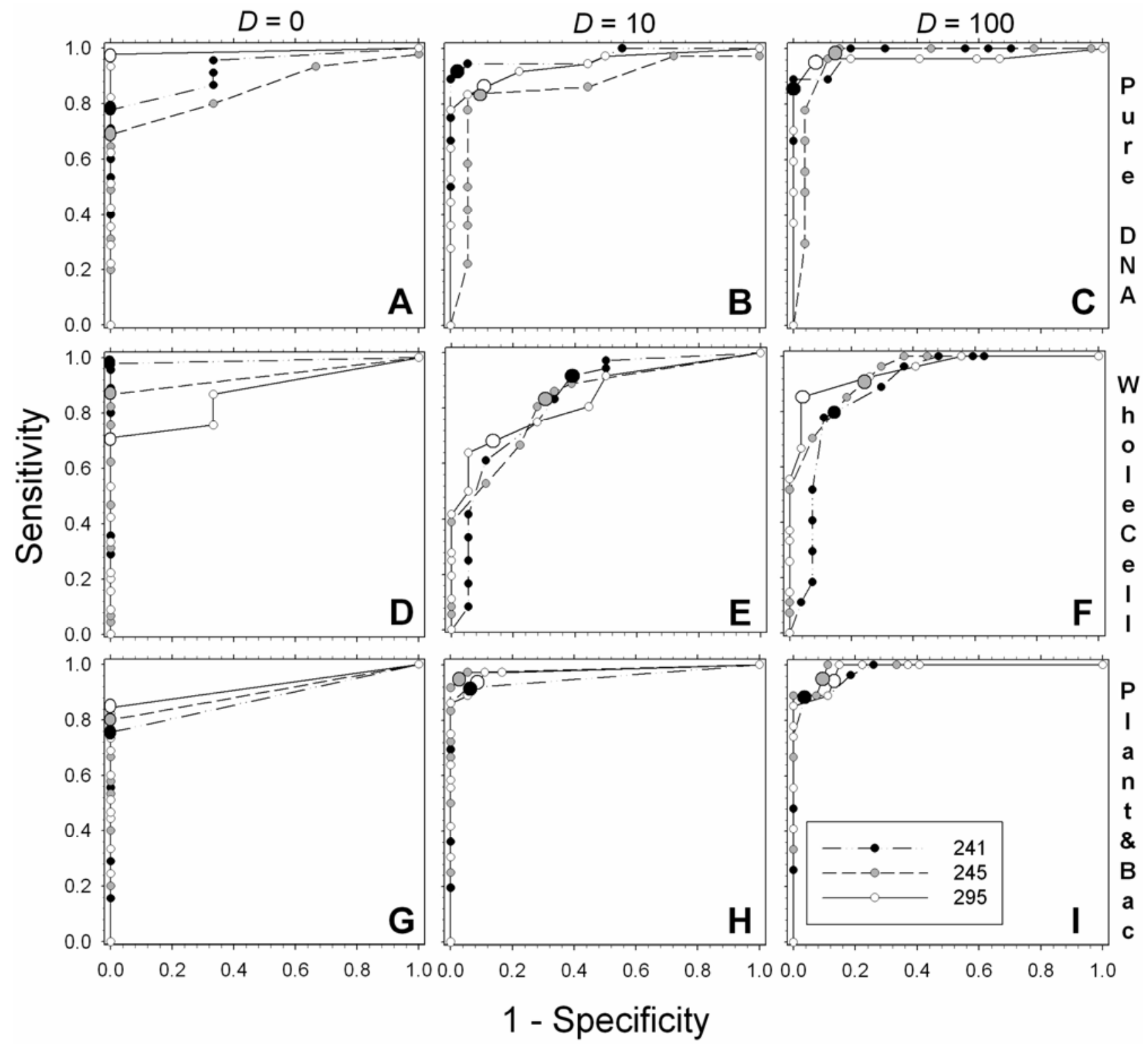

Fig. 4. Receiver operating characteristic (ROC) curves for qPCR performed on serial dilutions of $\mathbf{A}$, $\mathbf{B}$, and $\mathbf{C}$, genomic DNA extracted from pure cultures of Xanthomonas fragariae, $\mathbf{D}, \mathbf{E}$, and $\mathbf{F}$, whole cells of $X$. fragariae, and $\mathbf{G}, \mathbf{H}$, and $\mathbf{I}$, genomic DNA extracted from mixtures of crown tissue and bacteria. Reactions were conducted with the qPCR primer sets q241, q245, and q295 at the tolerance thresholds $\left(D_{\text {thresh }}\right) \mathbf{A}, \mathbf{D}$, and $\mathbf{G}, D=0, \mathbf{B}, \mathbf{E}$, and $\mathbf{H}, D=10$, and $\mathbf{C}, \mathbf{F}$, and I, $D=$ 100. The tolerance threshold is an arbitrarily chosen cell density used to partition the data in to cases (i.e., dilutions where cell density exceeded the tolerance) and controls (i.e., dilutions where cell density did not exceed the tolerance). The larger symbols shown in each figure represent the cutpoints identified by Youden's index and are listed in Table 4. The false positive proportion (i.e., 1 - specificity), is the proportion of reactions that were incorrectly classified as exceeding the tolerance from the set of samples that actually were below the tolerance (i.e., the number of controls incorrectly classified as a case). The true positive proportion, or the sensitivity, is the proportion of reactions that were correctly classified as exceeding the tolerance from the population of samples that actually were above the tolerance (i.e., the number of cases that were correctly classified as such).

Lastly, although three primer pairs were developed, only one set is actually required for pathogen detection. Nevertheless, because no one test is perfectly sensitive or specific under all conditions, the use of multiple primers can be of value if one needs to increase the level specificity (i.e., reducing the number of false positive test results), but at the cost decreased sensitivity. This can be done under the context of aggregate or herd testing, as it is referred to in the veterinary literature $(2,18)$, and is a natural extension in diagnostic testing.

\section{ACKNOWLEDGMENTS}

We thank J. Crane, P. Edmonds, C. Hsu, E. Pfeufer, and C. Yeh for technical assistance and thoughtful inputs. Financial support was provided by USDA-ARS-CRIS 1275-21220-181-00D and 1275-21000-15900D. The use of trade, firm, or corporation names in this publication is for the information and convenience of the reader. Such use does not constitute an official endorsement or approval by the United States Department of Agriculture or the Agricultural Research Service of any product or service to the exclusion of others that may be suitable.

\section{LITERATURE CITED}

1. Bergmann, R., Ludbrook, J., and Spooren, W. P. J. M. 2000. Different outcomes of the Wilcoxon-Mann-Whitney test from different statistics packages. Am. Stat. 54:72-77.

2. Christensen, J., and Gardner, I. A. 2000. Herd-level interpretation of test results for epidemiologic studies of animal diseases. Prev. Vet. Med. 45:83-106.

3. da Silva, A. C. R., Ferro, J. A., Reinach, F. C., Farah, C. S., Furlan, L. R., Quaggio, R. B., Monteiro-Vitorello, C. B., Van Sluys, M. A., Almeida, N. F., Alves, L. M. C., do Amaral, A. M., Bertolinni, M. C., Camargo, I. E. A., Camarotte, G., Cannavan, F., Cardozo, J., Chambergo, F., Ciapina, L. 
P., Cicarelli, R. M. B., Coutinho, L. L., Cursino-Santos, J. R., El-Dorry, H., Faria, J. B., Ferreira, A. J. S., Ferreira, R. C. C., Ferro, M. I. T., Formighieri, E. F., Franco, M. C., Greggio, C. C., Gruber, A., Katsuyama, A. M., Kishi, L. T., Leite, R. P., Lemos, E. G. M., Lemos, M .V. F., Locall, E. C., Machado, M. A., Madeira, A. M. B. N., Marinez-Rossi, N. M., Martins, E. C., Meidanis, J., Menck, C. F. M., Miyaki, C. Y., Moon, D. H., Moreira, L. M., Novo, M. T. M., Okura, V. K., Oliveira, M. C., Oliveira, V. R., Pereira, H. A., Rossi, A., Sena, J. A. D., Silva, C., de Souza, R. F., Spinola, R. A. F., Takita, M. A., Tamura, R. E., Teixera, E. C., Tezza, R. I. D., Trinidade dos Dantos, M., Truffi, D., Tsai, S. M., White, F. F., Setubal, J. C., and Kitajima, J. P. 2002. Comparison of the genomes of two Xanthomonas pathogens with differing host specificities. Nature 417:459-463.

4. DeLong, E. R., DeLong, D. M., and Clarke-Pearson, D. L. 1988. Comparing the area under two or more correlated receiver operating characteristic curves: A nonparametric approach. Biometrics 44:837-845.

5. Dewdney, M. M., Biggs, A. R., and Turechek, W. W. 2007. A statistical comparison of the blossom blight forecasts of MARYBLYT and Cougarblight with receiver operating characteristic (ROC) curve analysis. Phytopathology 97:1164-1176.

6. Edwards, K., Logan, J., and Saunders, N. (eds.). 2004. Page 346 in: RealTime PCR: An Essential Guide. Horizon Bioscience, Wymondham, Norfolk.

7. Geng, S., Campbell, R. N., Carter, M., and Hills, F. J. 1983. Qualitycontrol programs for seedborne pathogens. Plant Dis. 67:236-242.

8. Hanley, J. A., and McNeil, B. J. 1982. The meaning and use of the area under the receiver operating characteristic (ROC) curve. Radiology 143:29-36.

9. Hartung, J. S., and Pooler, M. R. 1997. Immunocapture and multiplexedPCR assay for Xanthomonas fragariae, causal agent of angular leaf spot disease. Acta Hortic. 439:821-828.

10. Hayward, A. C. 1960. A method for characterizing Pseudomonas solanacearum. Nature 186:405-406.

11. Hazel, W. J., Civerolo, E. L., and Bean, G. A. 1980. Procedures for growth and inoculation of Xanthomonas fragariae, causal organism of angular leaf spot of strawberry. Plant Dis. 64:178-181.

12. Hughes, G., and Madden, L. V. 2003. Evaluating predictive models with application in regulatory policy for invasive weeds. Agric. Syst. 76:755774.

13. Hughes, G., McRoberts, N., and Burnett, F. J. 1999. Decision-making and diagnosis in disease management. Plant Pathol. 48:147-153.

14. Kennedy, B. W., and King, T. H. 1962. Angular leaf spot of strawberry caused by Xanthomonas fragariae sp. nov. Phytopathology 52:873-875.

15. Lee, B. M., Park, Y. J., Park, D. S., Kang, H. W., Kim, J. G., Song, E. S., Park, I. C., Yoon, U. H., Hahn, J. H., Koo, B. S., Lee, G. B., Kim, H., Park, H. S., Yoon, K. O., Kim, J. H., Jung, C. H., Koh, N. H., Seo, J. S., and Go, S. J. 2005. The genome sequence of Xanthomonas oryzae pathovar oryzae KACC10331, the bacterial blight pathogen of rice. Nucleic Acids Res. 33:577-586.

16. Li, W., Hartung, J. S., and Levy, L. E. 2006. Quantitative real time PCR for detection and identification of Candidatus Liberibacter species associated with citrus huanglongbing. J. Microbiol. Methods 66:104-115.

17. Maas, J. L., Pooler, M. R., and Galleta, G. J. 1995. Bacterial angular leafspot disease of strawberry: Present status and prospects for control. Adv. Strawberry Res. 14:18-24.

18. Martin, S. W., Shoukri, M., Thorburn, M. A. 1992. Evaluating the health status of herds based on tests applied to individuals. Prev. Vet. Med. 14:33-43.

19. Metz, C. E. 1978. Basic principles of ROC analysis. Nucl. Med. 8:283298.

20. Milholland, R. D., Ritchie, D. F., Daykin, M. E., and Gutierrez, W. A. 1996. Multiplication and translocation of Xanthomonas fragariae in strawberry. Adv. Strawberry Res. 15:13-17.

21. Mullis, K. B., and Faloona, F. A. 1987. Specific synthesis of DNA in vitro via a polymerase catalized chain reaction. Method. Enzymol. 55:335-350.

22. Newcombe, R. G. 2006. Confidence intervals for an effect size measure based on the Mann-Whitney statistic. Part 1: General issues and tail-areabased methods. Stat. Med. 25:543-557.

23. Newcombe, R. G. 2006. Confidence intervals for an effect size measure based on the Mann-Whitney statistic. Part 2: Asymptotic methods and evaluation. Stat. Med. 25:559-573.

24. Pooler, M. R., Ritchie, D. F., and Hartung, J. S. 1996. Genetic relationships among strains of Xanthomonas fragariae based on random amplified polymorphic DNA PCR, repetitive extragenic palindromic PCR, and enterobacterial repetitive intergenic consensus PCR data and generation of multiplexed PCR primers useful for the identification of this pathogen. Appl. Environ. Microbiol. 62:3121-3127.

25. Schulzer, M. 1994. Diagnostic tests - a statistical review. Muscle Nerve 17:815-819.

26. Sen, P. K. 1960. On some convergence properties of $U$-statistics. Calcutta Stat. Assoc. 10:1-18.

27. Smith, I. M., McNamar, D. G., Scott, P. R., and Harris, K. M. (eds). 1992. Xanthomonas fragariae. Page 829-833 in: Quarantine Pests for Europe. Data Sheets on European Communities and for the European and Mediterranean Plant Protection Organization. Cab International, Wallingford, UK.

28. Turechek, W. W., and Wilcox, W. F. 2005. Evaluating predictors of apple scab with receiver operating characteristic curve analysis. Phytopathology 95:679-691.

29. Twengström, E., Sigvald, R., Svensson, C., Yuen, J. 1998. Forecasting sclerotinia stem rot in spring sown oilseed rape. Crop Prot. 17:405-411.

30. Vega, F., Medeiros, J. L., and Luthra, R. 2002. Taqman PCR in the detection and quantification of chromosomal translocations in follicular lymphoma, mantle cell lymphoma and chronic myeloid leukemia: TaqMan real-time PCR assay. Internet J. Pathol. (ISSN 1528-8307):2(1).

31. Yuen, J., and Hughes, G. 2002. Bayesian analysis of plant disease prediction. Plant Pathol. 51:407-412.

32. Yuen, J., Twengström, E., and Sigvald, R. 1996. Calibration and verification of risk algorithms using logistic regression. Eur. J. Plant Pathol. 102:847-854. 